\title{
Challenges and Pitfalls in the Design and Reporting of Qualitative Research in the Health Sciences: Reflections from a Referee and Reviewer
}

\author{
Carl Abelardo T. Antonio, MD, MPH ${ }^{1,2}$ \\ ${ }^{1}$ Department of Applied Social Sciences, The Hong Kong Polytechnic University, Kowloon, Hong Kong \\ ${ }^{2}$ Department of Health Policy and Administration, College of Public Health, University of the Philippines Manila
}

\begin{abstract}
This paper aims to highlight some of the common areas of concern in qualitative research proposals and manuscripts, gleaned from the authors' first-hand experience as an external referee and peer-reviewer. The purpose is to provide broad guidance to researchers who are contemplating on writing a research proposal or journal manuscript using a qualitative approach. The three issues are (1) application of the generic label "qualitative" when proponents or authors describe the study design; (2) overreliance on, and even misuse of, interviews and focus groups for data collection; and (3) misconceptions on the process of qualitative data analysis. Practice points are offered on how researchers can avoid these missteps.
\end{abstract}

Research has been characterized as a quest for knowledge, and it has been proposed that both qualitative and quantitative approaches uncover different dimensions of "truth". The predominance of a positivist ontology in health research in the Philippines and elsewhere, coupled with intense methodological training in quantitative approaches, however, has relegated qualitative research to second-class status. Improving the quality of qualitative research work by addressing some of the issues outlined in this paper is one way of moving past this situation.

Key Words: qualitative research, data collection, data analysis, research report, journal article

\section{INTRODUCTION}

In recent years and specifically within the field of health sciences in the Philippines, there has been a notable increase in requests for and submissions of proposals for funding and manuscripts for publication using qualitative design in the health sciences. ${ }^{1,2}$ This phenomenon may signal the increasing recognition by policymakers, program managers, editors, and other scholars of the role of evidence generated from qualitative studies in informing research, policy, and practice.

Such enthusiasm, however, is dampened by issues and challenges that impact on the methodological soundness of the proposed, or completed, work $\mathrm{k}^{3-5}$ and, in the case of the latter, may contribute to what can be considered as research waste (i.e., research findings that are never disseminated or utilized because of poor design). ${ }^{6-9}$ This situation is more alarming, if not outright scandalous, in the case of funded research that proposes to utilize (or has actually expended)

Corresponding author: Carl Abelardo T. Antonio, MD, MPH Department of Applied Social Sciences,

The Hong Kong Polytechnic University

11 Yuk Choi Road, Hung Hom,

Kowloon, Hong Kong SAR

Email: carl-abelardo.antonio@connect.polyu.hk money from the government or private donors.

This paper was, thus, conceptualized to highlight some of the common areas of concern in qualitative research proposals and manuscripts, gleaned from the authors' firsthand experience as an external referee and peer-reviewer. 
The purpose is to provide broad guidance to researchers who are contemplating on writing a research proposal or journal manuscript using a qualitative approach.

At the outset, it must be emphasized that the issues mentioned in the following pages are neither exhaustive nor definitive, but should be considered as a starting point for discussion and healthy debate by the local academic community. This paper is also not intended to serve as an overview or a comprehensive review of qualitative research. Researchers are instead referred to sources cited in the references list for further and more in-depth information. Finally, readers are cautioned from overemphasizing methods in their future work as a result of perusing this manuscript, as the methodological dimension is but one of the considerations in qualitative research. ${ }^{10}$

\section{ISSUE NO. 1: "QUALITATIVE” AS A RESEARCH DESIGN}

The first and most common issue encountered in proposals and manuscripts is the application of the generic label "qualitative" when proponents or authors are asked to describe the study design. Whereas more specific terminologies are used (e.g., cross-sectional study, casecontrol study, single-group pretest-posttest evaluation), and a correspondingly more robust justification offered, for quantitative-oriented studies, researchers, it appears, are at a loss for words to characterize, much less describe, the type of qualitative study that they wish to carry out. The typical scenario is for researchers (including myself during my initial foray into the field) to simply state, "This proposed research will use a qualitative study design," or in the case of a manuscript, "This study utilized a qualitative approach to answer the study objectives." Full stop.

It bears pointing out, however, that a "qualitative" label is non-specific and meaningless as a research design since qualitative research is, in actuality, a heterogeneous grouping of approaches whose only commonality is that they are not quantitative. ${ }^{11,12}$ More specifically, qualitative designs are those that primarily deals with the meaning of phenomena. ${ }^{13}$ The heterogeneity of this family of research approaches stems from the broad spectrum of ontological (i.e., whether reality exists or is constructed) and epistemological (i.e., whether knowledge is gained objectively or subjectively) tradition in which the design is embedded, giving rise to designs that embrace a post-positivist framework, on the one hand, and those that espouse a constructionist view, on the other. ${ }^{14,15}$ While the nomenclature within the qualitative tradition is rather diverse (one paper ${ }^{16}$ claims that there are over 20 variants of qualitative research approaches), there are five basic qualitative research designs ${ }^{17}$ that researchers should be familiar with (described briefly in Table 1). In contrast, quantitative research is primarily rooted in the positivist tradition (i.e., a realist ontology and objective epistemology) and, within the context of epidemiologic research, are attempts to emulate the experimental study design. ${ }^{18}$

The importance of choosing the right qualitative research design is its close link to both upstream (i.e., assumptions relating to ontology, epistemology, and axiology; the type of research question being asked) and downstream (i.e., data collection methods and tools, including study participants, study site, ethics, and fieldwork; and analytic strategy, including data handling, data interpretation, and quality) considerations or "choice moments". ${ }^{19}$ In other words, stating that one is using a particular research design discloses the researchers' lens or perspective, and evokes an expectation in the reader (of the proposal or manuscript) of congruence or alignment with what one plans to do, or has done, in the research and the results that are generated or presented.

Given the diversity of qualitative research designs, a good practice for scholars, then, is to state and describe the

Table 1. Five basic qualitative research designs

\begin{tabular}{|c|c|c|}
\hline Design & Research problem & Key references \\
\hline Narrative research & $\begin{array}{l}\text { Tell stories of individual } \\
\text { experiences }\end{array}$ & $\begin{array}{l}\text { - Clanidinin, DJ. (2013). Engaging in narrative inquiry. Walnut Creek, CA: Left Coast Press } \\
\text { - Riessman, CK. (2008). Narrative methods for the human sciences. Thousand Oaks, CA: Sage. }\end{array}$ \\
\hline Phenomenology & $\begin{array}{l}\text { Describe the essence of } \\
\text { a lived phenomenon }\end{array}$ & $\begin{array}{l}\text { - Moustakas, C. (1994). Phenomenological research methods. Thousand Oaks, CA: Sage. } \\
\text { - van Manen, M. (2014). Phenomenology of practice: Meaning-giving methods in } \\
\text { phenomenological research and writing. Walnut Creek, CA: Left Coast Press }\end{array}$ \\
\hline Grounded theory & $\begin{array}{l}\text { Ground a theory in the } \\
\text { views of participants }\end{array}$ & $\begin{array}{l}\text { - Glaser, S, \& Corbin, AL. (1967). The discovery of grounded theory: Strategies for qualitative } \\
\text { research. New York: Aldine Pub. } \\
\text { - Strauss, AL, \& Corbin, JM. (1998). Basics of qualitative research: Techniques and procedures } \\
\text { for developing grounded theory (2nd ed.). Thousand Oaks, CA: Sage. } \\
\text { - Charmaz, K. (2014). Constructing grounded theory (2nd ed.). Thousand Oaks, CA: Sage. }\end{array}$ \\
\hline Ethnography & $\begin{array}{l}\text { Describe and interpret } \\
\text { the shared patterns of } \\
\text { culture of a group }\end{array}$ & $\begin{array}{l}\text { - Fetterman, D. (2010). Ethnography: Step-by-step (3rd ed.). Thousand Oaks, CA: Sage. } \\
\text { - Wolcott, H. (2008). Ethnography: A way of seeing (2nd ed.). Lanham, MD: Altamira Press. }\end{array}$ \\
\hline Case study & $\begin{array}{l}\text { Provide an in-depth } \\
\text { understanding of } \\
\text { a case or cases }\end{array}$ & $\begin{array}{l}\text { - Stake, R. (1995). The art of case study research. Thousand Oaks, CA: Sage. } \\
\text { - Yin, R. (2014). Case study research: Design and methods (5th ed.). Thousand Oaks, CA: Sage. } \\
\text { - George, A., \& Bennett, A. (2005). Case studies and theory development in the social sciences. } \\
\text { Cambridge, Mass.: MIT Press. }\end{array}$ \\
\hline
\end{tabular}

Adapted from (17) 
approach that will be used in the proposed study (or was used, in the case of a journal manuscript) for purposes of transparency - this is the main aim - and to also serve as an anchor or point of reference for the researcher or author in developing the other parts of the proposal or manuscript. To illustrate, in one proposal that I wrote, I labeled the study design as a "qualitative, exploratory, multiple, embedded case study design with a critical realist orientation." I spent about a third of a page (within the five-page limit for the methodology section) describing and explaining the choice of the approach. I also frequently went back to the design to ensure coherence with the study methods as it was being negotiated within the project team and with the funder and reviewers.

\section{ISSUE NO. 2: "KII" AND "FGD" FOR DATA COLLECTION}

Interviews and focus groups are typically the most commonly used methods of data collection in the proposals or manuscripts that I have reviewed, and this is consistent with what has been observed in the health sciences literature in general. ${ }^{20-26}$ Aside from the lack of detail on the procedures for conducting interviews and focus groups that outlines the sequence of steps that will be undertaken/were done by the researcher/s to implement the method (including a statement on access to participants and instruments to be used for data collection), an observation that also holds for proposals or manuscripts in the qualitative tradition that I encountered, three common pitfalls are worth noting.

First, "interview" is typically seen as a label for a single method (key informant interview, or KII, being a favorite label that I have encountered). That is, researchers are wont to view interviewing as a unitary method, where it constitutes several variants that are classified in terms of configuration (i.e., structured, semi-structured, or unstructured), medium (i.e., face-to-face, telephone, video call), and participant (i.e., ordinary person, key informant, expert), among others. ${ }^{27-29}$ Any combination of these three have implications for fieldwork preparation, including selection/sampling of participants, design of interview questions, and the interview technique itself.

Focus groups, on the other hand, are interpreted as "group interviews" in a narrow sense. This means that some researchers will typically opt to convert what was supposed to be individual interviews into a simultaneous data collection activity for the target informants who happen to be conveniently gathered in one setting (i.e., captive audience such as those attending a meeting or a workshop), usually driven by feasibility considerations. The original intent, however, still is manifest with the use of an identical set of guide questions for both interview and focus group. The purpose and mechanics of interviews and focus groups are, however, disparate. Specifically, focus group discussion are aimed at generating ideas from group interaction, which may highlight areas of consensus and diversity, whereas interviews are mainly designed to elicit information from one respondent at a time..$^{25,29-31}$ In terms of implementation, the skill set required for interviewers is primarily on their capacity to engage in a dialogue, whereas focus groups require a facilitator who must successfully conduct the conversation within a group setting. ${ }^{25,29-31}$

The third concern for methods of data collection is the seeming fixation with interviews and focus groups, to the neglect of other methods in qualitative research (Table 2), each of which may offer a "different slice of reality". ${ }^{32}$ The use

Table 2. Common methods of data collection in qualitative research

\begin{tabular}{|c|c|c|c|}
\hline Method & Description & Advantages & Disadvantages \\
\hline Interviews & $\begin{array}{l}\text { Intensive exploration of perspectives } \\
\text { of individuals or small groups on a } \\
\text { particular phenomenon }\end{array}$ & $\begin{array}{l}\text { - Adaptable } \\
\text { - Practical } \\
\text { - Flexible }\end{array}$ & $\begin{array}{l}\text { - Trustworthiness of data } \\
\text { - Ecological validity } \\
\text { - Interviewer bias } \\
\text { - Social desirability bias }\end{array}$ \\
\hline $\begin{array}{l}\text { Focus group } \\
\text { discussion }\end{array}$ & $\begin{array}{l}\text { Interview with at least four } \\
\text { interviewees led by a moderator. } \\
\text { Focus in on construction of meaning } \\
\text { of a particular phenomenon within } \\
\text { a group setting. }\end{array}$ & $\begin{array}{l}\text { Same as interview plus: } \\
\text { - Stimulating } \\
\text { - Cumulative } \\
\text { - Elaborative }\end{array}$ & $\begin{array}{l}\text { - Resource- and effort-intensive } \\
\text { - Group-think } \\
\text { - Too much data (how to analyze) }\end{array}$ \\
\hline $\begin{array}{l}\text { Participant } \\
\text { observation }\end{array}$ & $\begin{array}{l}\text { Systematic description of events, } \\
\text { behaviors and artifacts in a } \\
\text { chosen setting, accomplished by } \\
\text { active use of senses (i.e., looking, } \\
\text { listening and asking). Captures } \\
\text { nonverbal expressions. }\end{array}$ & $\begin{array}{l}\text { - Detailed description } \\
\text { - Researcher can vie/ } \\
\text { participate in unscheduled } \\
\text { events } \\
\text { - Access to "backstage" culture }\end{array}$ & $\begin{array}{l}\text { - Defining the role of the researcher in the field } \\
\text { - Informed consent } \\
\text { - Access to site and privacy concerns }\end{array}$ \\
\hline Visual methods & $\begin{array}{l}\text { Analysis of data in visual materials } \\
\text { (e.g., film, photography, maps, } \\
\text { diagrams, drawings), as against } \\
\text { text, to study social phenomena }\end{array}$ & $\begin{array}{l}\text { - Able to express things that } \\
\text { are difficult to put into words } \\
\text { - Allow for multi-dimensional } \\
\text { perspective }\end{array}$ & $\begin{array}{l}\text { - Difficult to summarize } \\
\text { - May result to data loss } \\
\text { - Ethical issues on privacy and confidentiality } \\
\text { of persons in the visual material }\end{array}$ \\
\hline
\end{tabular}

Note: The author synthesized some of the material in this table from discussions of students enrolled in the course "APSS6002. Research Methodology I: Qualitative Methods" in The Hong Kong Polytechnic University during First Semester, Academic Year 2018-2019.

Sources: 62,63 
of complementary methods of data collection also allows for one mode of triangulation, which may produce a more robust result when compared with just using one or a couple. ${ }^{33}$ An illustrative example is from a concept for research on interagency collaboration that I was working on, in which I initially thought of obtaining data through interviews alone. As shown in Table 3, however, a combination of methods may be more advantageous as it will provide me with a far richer view on how the interagency body functions. Of course, the degree to which each method can be employed will be determined by feasibility and ethical constraints/limitations.

A good practice point for researchers, then, is to consider the use of method/s that would contribute to or enhance the plausibility of the result of the chosen study design. The specific approach for collecting data using each method should also be outlined in the proposal document; an alternative is to cite an author or text from which the procedure was adopted.

\section{ISSUE NO. 3: CODING, THEMATIC ANALYSIS, AND EXTENSIVE QUOTES}

The final issue is the seeming confusion on the analysis of qualitative data, which takes three typical forms: (a) labeling "coding" as the method of analysis without any proper description on how the codes were generated; (b) overreliance on thematic analysis as a method for transforming raw data into meaningful answers to research questions; and (c) presentation of an overwhelming number of quotes from informants in the results section of manuscripts.

The result is what is typically referred to as "garden path analysis" 34 (i.e., the researcher simply recapitulates observations or data gathered from the field without any attempt at integrating or synthesizing these into coherent and meaningful findings that address the research question or objective), and consequently a very thin, as opposed to Geertz's thick, ${ }^{35}$ description of the phenomenon. It is also not uncommon to see what is purported to be "themes" as merely being the categorization of answers to the questions propounded during the interview or focus group. It is as if one administered a questionnaire on a representative sample of the population and then reported on the answers of individual participants on each item covered by the tool, leaving the reader to make sense of all such data.

The above-outlined practices lead to the perception that qualitative data analysis is a "black box," a mystery, a secret process that only initiates can understand, ${ }^{36-39}$ a contravention of a core principle of scientific inquiry that demands transparency in the research process for accountability and replication..$^{40-43}$

Researchers must bear in mind that analysis is about searching for patterns or regularities in the data. ${ }^{44-46}$ It is

Table 3. Example on the complementarity of different methods of data collection

\begin{tabular}{|c|c|c|c|}
\hline Method & Slice of reality that might be obtained & What researcher may not "see" & Limitations/constraints \\
\hline $\begin{array}{l}\text { Review of policy } \\
\text { documents forming } \\
\text { the interagency body, } \\
\text { laying down their roles } \\
\text { and responsibilities }\end{array}$ & $\begin{array}{l}\text { What each agency/stakeholder } \\
\text { ought to be doing in the context of } \\
\text { interagency work }\end{array}$ & $\begin{array}{l}\text { - Actual performance } \\
\text { - Degree of cooperation between } \\
\text { and among agencies }\end{array}$ & $\begin{array}{l}\text { - Access may not be an issue since } \\
\text { these are public documents }\end{array}$ \\
\hline $\begin{array}{l}\text { Interviews with } \\
\text { representatives } \\
\text { from each agency }\end{array}$ & $\begin{array}{l}\text { - What each agency/stakeholder think } \\
\text { they should be doing OR What each } \\
\text { agency/stakeholder is actually doing } \\
\text { - What each agency/stakeholder think } \\
\text { others should be contributing to } \\
\text { interagency work }\end{array}$ & $\begin{array}{l}\text { - Actual performance, since most } \\
\text { likely what I will obtain are the } \\
\text { socially desirable responses }\end{array}$ & $\begin{array}{l}\text { - Primarily administrative, since } \\
\text { I will be speaking with an } \\
\text { authorized agency representative. } \\
\text { It might be difficult to get contrary } \\
\text { views/opinions }\end{array}$ \\
\hline $\begin{array}{l}\text { Review of minutes } \\
\text { of meetings of the } \\
\text { interagency body }\end{array}$ & $\begin{array}{l}\text { - Respective contribution of each, and } \\
\text { power relations among (e.g., who } \\
\text { leads discussions, alliances, etc.), } \\
\text { agency/stakeholder } \\
\text { - Issues/concerns within and between } \\
\text { each agency/stakeholder } \\
\text { - What is said/not said }\end{array}$ & $\begin{array}{l}\text { - Relations/degree of cooperation } \\
\text { outside of the meetings } \\
\text { - Parts of meeting proceedings } \\
\text { that are off the record or not } \\
\text { captured by documentor } \\
\text { - Context and manner in which } \\
\text { each statement was said (i.e., } \\
\text { non-verbal communication) }\end{array}$ & $\begin{array}{l}\text { Primarily administrative, since } \\
\text { some parts of the minutes may be } \\
\text { protected by certain privileges that } \\
\text { restrict access by non-members }\end{array}$ \\
\hline $\begin{array}{l}\text { Official photographs } \\
\text { documenting } \\
\text { meeting/activity of } \\
\text { interagency body }\end{array}$ & $\begin{array}{l}\text { Power relations among agency/ } \\
\text { stakeholder (e.g., who is seated next } \\
\text { to whom, clustering, etc.) }\end{array}$ & $\begin{array}{l}\text { - Context in which activities } \\
\text { depicted in the visual method } \\
\text { took place } \\
\text { - Events outside the frame }\end{array}$ & $\begin{array}{l}\text { Administrative and ethical: In } \\
\text { addition to access to official photos, } \\
\text { I will need individual consent from } \\
\text { each meting participant if I will be } \\
\text { taking photos myself }\end{array}$ \\
\hline $\begin{array}{l}\text { Observation of } \\
\text { meeting/discussion of } \\
\text { interagency body }\end{array}$ & $\begin{array}{l}\text { - Respective contribution of each, and } \\
\text { power relations among (e.g., who } \\
\text { leads discussions, alliances, etc.), } \\
\text { agency/stakeholder } \\
\text { - What is said/not said } \\
\text { - Who is at the table/not at the table }\end{array}$ & $\begin{array}{l}\text { Relations/degree of cooperation } \\
\text { outside of the meetings }\end{array}$ & $\begin{array}{l}\text { - Administrative: Access to entire } \\
\text { meeting may be restricted if the body } \\
\text { decides to go into executive session } \\
\text { - Ethical: Consent of the body as } \\
\text { a whole, vs individual consent to } \\
\text { be observed }\end{array}$ \\
\hline
\end{tabular}

Source: The author 
mainly an iterative process that follows a distinct set of stages or phases: data reduction (i.e., converting the mass of text into analyzable components, completed through segmentation, and the application of labels to these components, or what is known as coding ${ }^{47}$ ), pattern-seeking (i.e., discovering relationships, associations, connections, divergences, and isolations in the coded data), claims verification (i.e., validating the identified patterns through such methods as triangulation, participant feedback, etc.), and results presentation (i.e., visualization of data through the use of tables, models, etc.). ${ }^{48}$ From the preceding, it must be emphasized that coding is but one step in the analytic process and that it is not the endpoint of analysis.

Different methods of data analysis, it is suggested, can be carried out depending on the research question at hand, from a descriptive approach (e.g., qualitative content analysis) to one that generates a theoretical proposition (e.g., grounded theory), akin to using descriptive and inferential statistics in quantitative research. ${ }^{49}$ It is also worth noting that each research design has a corresponding method of data analysis, which is related to the idea of choice moments mentioned earlier in this manuscript (Table 4).

The third point is concerning presentation of analyzed data. While it may be true that a detailed description of a phenomenon can be achieved through a detailed narrative supported by representative quotes from informants, it bears pointing out that this is not the only means by which the results of qualitative research can be presented. In the same manner that tables and graphs can present the results for quantitative data in a form that can easily be grasped by the reader, data displays and visualization can be used to summarize qualitative data. ${ }^{48,50-52}$ Common types of data displays used by researchers include matrices, networks, flow charts, boxes, modified Venn diagram, taxonomy, ladder, and decision trees. ${ }^{53}$

In summary, researchers should ensure congruence of the analytic approach to the qualitative research design;

Table 4. Data analysis methods for each study design

\begin{tabular}{ll}
\hline \multicolumn{1}{c}{ Design } & \multicolumn{1}{c}{ Analytic approach/techniques } \\
Narrative & $\begin{array}{l}\text { - Presentation of chronology of unfolding } \\
\text { of events and turning points or epiphanies } \\
\text { (restorying) }\end{array}$ \\
\hline Phenomenology & $\begin{array}{l}\text { - Development of a composite description of } \\
\text { the "essence" of the experience incorporating } \\
\text { both textual and structural descriptions }\end{array}$ \\
\hline Grounded theory & $\begin{array}{l}\text { - Open coding, axial coding and selective } \\
\text { coding to generate proposition/s or } \\
\text { conditional matrix }\end{array}$ \\
\hline Ethnography & $\begin{array}{l}\text { - Description, analysis, and interpretation of } \\
\text { the culture-sharing group }\end{array}$ \\
\hline Case study & $\begin{array}{l}\text { - Detailed description of the case } \\
\text { - Pattern matching, explanation building, } \\
\text { time-series analysis, logic modelling, cross- } \\
\text { case synthesis }\end{array}$ \\
\hline
\end{tabular}

Sources: 17,64 outline the process of analysis to be undertaken (or at least cite the author of the procedure adopted); produce results that offer a more productive, thicker and more nuanced description of the data collected; and consider the use of data visualization in addition to representative quotes when reporting results.

\section{DISCUSSION}

The preceding paragraphs have briefly outlined three common issues encountered by the author in reviewing proposals or reports of qualitative research, namely: (1) application of the generic label "qualitative" when proponents or authors describe the study design; (2) overreliance on, and even misuse of, interviews and focus groups for data collection; and (3) misconceptions on the process of qualitative data analysis.

To be sure, these instances are not unique to the local setting but are instead part of a common concern shared by researchers elsewhere. ${ }^{3-5}$ In addition to contributing to the pile of research that is not utilized - by other researchers, by academics, practitioners, or policymakers - because of poor quality ${ }^{6-9}$, the persistence of the concerns outlined in this paper may affect the integrity and trustworthiness of qualitative research as a knowledge-generating discipline..$^{5,55}$

One way forward is for researchers is to carry out selfassessment on the completeness of their qualitative research proposal or manuscript against reporting checklists of the discipline. ${ }^{56,57}$ The same checklists can be used by referees for grant agencies, and journal reviewers and editors when evaluating submissions for funding or publication.

It is also possible that the three issues identified in this paper are but symptoms of the need to strengthen the methodological preparation of academics in the health sciences in the Philippines on the use of qualitative methodologies. Academic institutions in the health professions may want to explore further partnerships with colleagues in the social sciences as a means to eventually build an internal pool of researchers who have the requisite knowledge and skills to deploy qualitative research techniques in answering research questions on health.

Research has been characterized as a quest for knowledge, and it has been proposed that both qualitative and quantitative approaches uncover different dimensions of "truth" ${ }^{58}$ The predominance of a positivist ontology in health research, coupled with intense methodological training in quantitative approaches, however, has relegated qualitative research to second-class status. ${ }^{59-61}$ Improving the quality of qualitative research work (i.e., addressing some of the issues outlined in this paper) is one way of moving past this situation.

\section{Statement of Authorship}

The author confirms sole responsibility for the conception and preparation of the manuscript for this special article. 


\section{Author Disclosure}

The author is a technical referee for the Scientific Review Council of the National Institutes of Health (University of the Philippines Manila), and the Philippine Council for Health Research and Development (Department of Science and Technology, Republic of the Philippines); reviewer for the University of the Philippines Manila Research Ethics Board, and the Single Joint Research Ethics Board (Department of Health, Republic of the Philippines); and peer-reviewer and Associate Editor for Philippine Journal of Health Research and Development (published by the University of the Philippines Manila), and BMC Health Services Research and BMC Public Health (both published by BioMed Central Ltd./Springer Nature).

The views and opinions expressed in this article are those of the author and do not necessarily reflect the official policy or position of any of the institutions mentioned above.

\section{Funding Source}

No funding support.

\section{REFERENCES}

1. Trinidad JRE. Call for Proposals: AHEAD-HSPR Programs 2019. [Internet] [cited 2019 July 1]. Available from: http://www.pchrd. dost.gov.ph/index.php/news/6425-call-for-proposals-ahead-hsprprograms.

2. PCHRD. Call for Research Proposal - AHEAD-HPSR Program 2018. [Internet]. [cited 2019 July 1]. Available from: http://pchrd. dost.gov.ph/index.php/events/6328-call-for-research-proposal-aheadhpsr-program.

3. Mercado-MartinezFJ,Tejada-Tayabas LM,SpringettJ.Methodological issues in emergent evaluations of health programs: Lessons from Iberoamerica. Qualitative Health Research. 2008;18(9):1277-88. doi: 10.1177/1049732308321755.

4. Wisdom JP, Cavaleri MA, Onwuegbuzie AJ, Green CA. Methodological reporting in qualitative, quantitative, and mixed methods health services research articles. Health Services Research. 2012;47(2):721-45. doi: 10.1111/j.1475-6773.2011.01344.x.

5. Malterud K. Qualitative research: standards, challenges, and guidelines. The Lancet. 2001;358(9280):483-8. doi: 10.1016/S01406736(01)05627-6.

6. Chan A-W, Song F, Vickers A, Jefferson T, Dickersin K, Gøtzsche $\mathrm{PC}$, et al. Increasing value and reducing waste: addressing inaccessible research. The Lancet. 2014;383(9913):257-66. doi: 10.1016/S01406736(13)62296-5.

7. Glasziou P, Chalmers I. Research waste is still a scandal—an essay by Paul Glasziou and Iain Chalmers. BMJ. 2018:k4645. doi: 10.1136/bmj. $\mathrm{k} 4645$.

8. Okumura Y. Reducing research waste through good reporting practices. Journal of Epidemiology. 2016;26(8):397-8. doi: 10.2188/ jea.JE20160105.

9. Wolfenden L, Ziersch A, Robinson P, Lowe J, Wiggers J. Reducing research waste and improving research impact. Australian and New Zealand Journal of Public Health. 2015;39(4):303-4. doi: 10.1111/1753-6405.12467.

10. Chamberlain K. Methodolatry and qualitative health research. Journal of Health Psychology. 2000;5(3):285-96. doi: 10.1177/135910530000500306.

11. Denzin NK, Lincoln YS. Introduction: The discipline and practice of qualitative research. In: Denzin NK, Lincoln YS, editors. The SAGE handbook of qualitative research. 5th ed. Thousand Oaks, California: Sage; 2017. p. 1-26.
12. Hammersley M. What is qualitative research? London: Bloomsbury Academic; 2013.

13. Dey I. What is qualitative data? Qualitative data analysis: A userfriendly guide for social scientists. London: New York: Routledge; 1993. p. 10-30.

14. Guba E, Lincoln Y, Lynham S. Paradigmatic controversies, contradictions, and emerging confluences. In: Denzin NK, Lincoln YS, editors. The SAGE handbook of qualitative research. 5th ed. Thousand Oaks, California: Sage; 2017. p. 108-50.

15. Savin-Baden M, Major CH. A brief history of philosophical perspectives. Qualitative research: The essential guide to theory and practice. Abingdon [England]: Routledge; 2013. p. 18-34.

16. Crowe M, Sheppard L. Qualitative and quantitative research designs are more similar than different. The Internet Journal of Allied Health Sciences and Practice. 2010;8(4):Article 5.

17. Creswell JW. Qualitative inquiry \& research design: Choosing among five approaches. 4th ed. Poth CN, editor. Los Angeles: SAGE; 2018.

18. Rothman KJ, Greenland S, Lash TL. Modern epidemiology. 3rd ed. Philadelphia: Wolters Kluwer Health/Lippincott Williams \& Wilkins; 2008.

19. Savin-Baden M, Major CH. Research choices and lenses. Qualitative research: The essential guide to theory and practice. Abingdon [England]: Routledge; 2013. p. 35-49.

20. Bender DE, Ewbank D. The focus group as a tool for health research: issues in design and analysis. Health Transition Review. 1994;4(1): 63-80.

21. Fontanella BJB, Campos CJG, Turato ER. Data collection in clinicalqualitative research: Use of non-directed interviews with open-ended questions by health professionals. Rev Latino-Am Enfermagem. 2006;14(5):812-20. doi: 10.1590/S0104-11692006000500025.

22. McGrath C, Palmgren PJ, Liljedahl M. Twelve tips for conducting qualitative research interviews. Medical teacher. 2018:1-5. doi: 10.1080/0142159X.2018.1497149.

23. Nunkoosing K. The problems with interviews. Qualitative Health Research. 2005;15(5):698-706. doi: 10.1177/1049732304273903.

24. Pope C. Qualitative methods in research on healthcare quality. Quality and Safety in Health Care. 2002;11(2):148-52. doi: 10.1136/ qhc.11.2.148.

25. Tausch AP, Menold N. Methodological aspects of focus groups in health research: Results of qualitative interviews with focus group moderators. Global Qualitative Nursing Research. 2016;3:1-12. doi: 10.1177/2333393616630466.

26. Sánchez-Gómez MC, Martín-Cilleros MV. Implementation of focus group in health research. In: Costa A, Reis L, Neri de Sousa F, Moreira A, Lamas D, editors. Computer supported qualitative research Studies in systems, decision and control. 71: Springer, Cham; 2017.

27. Rabionet SE. How I learned to design and conduct semi-structured interviews: An ongoing and continuous journey. Qualitative Report. 2011;16(2):563-6.

28. Turner D. Qualitative interview design: A practical guide for novice investigators. The Qualitative Report. 2010;15(3):754-60.

29. Byrne B. Qualitative interviewing. In: Seale C, editor. Researching society and culture. 4th ed. Thousand Oaks, CA: Sage; 2018. p. 217-36.

30. O. Nyumba T, Wilson K, Derrick CJ, Mukherjee N. The use of focus group discussion methodology: Insights from two decades of application in conservation. Methods in Ecology and Evolution. 2018;9(1):20-32. doi: 10.1111/2041-210X.12860.

31. Tonkiss F. Focus groups. In: Seale C, editor. Researching society and culture. 4th ed. Thousand Oaks, CA: Sage; 2018. p. 237-56.

32. Denzin NK. The research act: A theoretical introduction to sociological methods. 3rd ed. Englewood Cliffs, N.J.: Prentice Hall; 1989.

33. Spicer N. Combining qualitative and quantitative methods. In: Seale C, editor. Researching society and culture. 4th ed. Thousand Oaks, CA: Sage; 2018. p. 305-20.

34. Bazeley P. Analysing qualitative data: More than 'identifying themes'. Malaysian Journal of Qualitative Research. 2009;2(2):6-22.

35. Geertz C. Thick description: Toward an interpretive theory of culture. The Cultural Geography Reader: Routledge; 1973 [2008]. p. 41-51. 
36. Bradley EH, Curry LA, Devers KJ. Qualitative data analysis for health services research: Developing taxonomy, themes, and theory. Health Services Research. 2007;42(4):1758-72. doi: 10.1111/j.14756773.2006.00684.x.

37. Rynes S, Gephart RP. From the editors: Qualitative research and the "Academy of Management Journal". The Academy of Management Journal. 2004;47(4):454-62.

38. Schiellerup P. Stop making sense: The trials and tribulations of qualitative data analysis. Area. 2008;40(2):163-71. doi: 10.1111/j.14754762.2008.00817.x.

39. Thorne S. Data analysis in qualitative research. Evidence Based Nursing. 2000;3(3):68-70. doi: 10.1136/ebn.3.3.68.

40. Data access and research transparency (DA-RT). Journal of Peace Research. 2015;52(4):417. doi: 10.1177/0022343315594562.

41. Kerr RL, de Vreese C, Logan RA, Steiner L, Pearson GS, Pierson CA. Authorship transparency in an era of accountability. Journalism \& Mass Communication Quarterly. 2018;95(4):871-85. doi: 10.1177/1077699018802805.

42. Kotz D, Tugwell P, Knottnerus JA. How to promote transparency and accountability in clinical and behavioral research. Journal of Clinical Epidemiology. 2016;70:275-. doi: 10.1016/j.jclinepi.2015. 07.001.

43. West R. Data and statistical commands should be routinely disclosed in order to promote greater transparency and accountability in clinical and behavioral research. Journal of Clinical Epidemiology. 2016;70:254-5. doi: 10.1016/j.jclinepi.2015.06.015.

44. Chenail R. Conducting qualitative data analysis: Qualitative data analysis as a metaphoric process. The Qualitative Report. 2012;17(1):248-53.

45. Ganapathy M. Qualitative data analysis: Making it easy for nurse researcher. International Journal of Nursing Education. 2016;8(2): 106-10. doi: 10.5958/0974-9357.2016.00057.X.

46. Seers K. Qualitative data analysis. Evidence - Based Nursing. 2012;15(1):2. doi: 10.1136/ebnurs.2011.100352.

47. Saldana J. The coding manual for qualitative researchers. Los Angeles: SAGE Publications Ltd.; 2016.

48. Miles MB, Huberman AM, Saldana J. Qualitative data analysis: A methods sourcebook. Thousand Oaks: SAGE Publications, Inc.; 2014

49. Paré M-H. Qualitative data analysis I: Design and concepts. 7th Annual IPSA-NUS Methods School for the Social Sciences Research Methods; Singapore2018.

50. Chandler R, Anstey E, Ross H. Listening to voices and visualizing data in qualitative research: Hypermodal dissemination possibilities. SAGE Open. 2015;5(2):1-8. doi: 10.1177/2158244015592166.
51. Henderson S, Segal EH. Visualizing qualitative data in evaluation research. New Directions for Evaluation. 2013;2013(139):53-71. doi: 10.1002/ev.20067.

52. Slone DJ. Visualizing qualitative information. Qualitative Report. 2009;14(3):489-97.

53. Verdinelli S, Scagnoli N, I. Data display in qualitative research. International Journal of Qualitative Methods. 2013;12(1). doi: 10.1177/160940691301200117.

54. Balachandran Nair L. Conference report: Scientific Integrity in Qualitative Research (SCIQUAL) Seminar 2017

55. Tagungsbericht: "Scientific Integrity in Qualitative Research" (SCIQUAL) Seminar 2017. 2017;19(1):9. doi: 10.17169/fqs-19. 1.2964 .

56. Jones J. Authenticity and scientific integrity in qualitative research. Journal of Obstetric, Gynecologic, \& Neonatal Nursing. 2013;42(4):401-2. doi: 10.1111/1552-6909.12229.

57. O'Brien BC, Harris IB, Beckman TJ, Reed DA, Cook DA. Standards for reporting qualitative research: A synthesis of recommendations. Academic Medicine. 2014;89(9):1245-51. doi: 10.1097/ACM. 0000000000000388.

58. Tong A, Sainsbury P, Craig J. Consolidated criteria for reporting qualitative research (COREQ): a 32-item checklist for interviews and focus groups. International Journal for Quality in Health Care. 2007;19(6):349-57. doi: 10.1093/intqhe/mzm042.

59. Al-Busaidi ZQ. Qualitative research and its uses in health care. Sultan Qaboos University medical journal. 2008;8(1):11-9.

60. Dahlberg K. Editorial. International Journal of Qualitative Studies on Health and Well-being. 2006;1(3):132. doi: 10.3402/qhw.v1i3.4925.

61. Rahman S, Majumder MAA. Qualitative research in medicine and healthcare: Is it subjective, unscientific or second class science? SE Asia J Pub Health. 2014;3(1):69-71. doi: 10.3329/seajph.v3i1.17715.

62. Shuval K, Harker K, Roudsari B, Groce NE, Mills B, Siddiqi Z, et al. Is qualitative research second class science? A quantitative longitudinal examination of qualitative research in medical journals. PLoS ONE. 2011;6(2):e16937. doi: 10.1371/journal.pone.0016937.

63. Bryman A. Social research methods. 5th ed. Oxford: Oxford University Press; 2016

64. Seale C. Researching society and culture. 4th ed. London: Sage; 2018.

65. Yin R. Case study research and applications: Design and methods. Thousand Oaks: SAGE Publications, Inc; 2017. 